\title{
Repeatability of central corneal thickness measurement with the Pentacam HR system
}

\author{
Reprodutibilidade da medida da espessura central \\ da córnea com o sistema Pentacam HR
}

Ruiz Simonato Alonso', Bruno Machado Fontes², Marcelo Palis Ventura', Renato Ambrósio Jr ${ }^{3}$

\begin{abstract}
Purpose: To assess the repeatability of central corneal thickness measurement at the geometrical center (Central Corneal Thickness - CCT) given by the Pentacam High Resolution (HR) Comprehensive Eye Scanner (Oculus, Wetzlar, Germany) over time. Methods: Prospective, single center, observational study. Two separate CCT measurements were taken by the Pentacam corneal tomography exam (CTm) 3 to 12 months apart, and compared. Results: One hundred and sixteen eyes $(n=116)$ of 62 health patients were included in this study. Average CCT in first and last visits was $541.6 \pm 37 \mu \mathrm{m}$ and $543.6 \pm 36.9 \mu \mathrm{m}$ respectively. Mean difference between both measurements was $9.2 \pm 6.4 \mu \mathrm{m}$, and there was no statistically significant difference in CCT measurement between visits, with good correlation between them $\left(\mathrm{P}=0.057, \mathrm{r}^{2}=0,9209\right)$. Conclusion: Pentacam $(\mathrm{HR}) \mathrm{CTm}$ gives repeatable CCT measurements over time.

Keywords: Cornea/anatomy \& histology; Corneal topography; Biometry/methods; Reproducibility of results; Diagnostic techniques, ophthalmological/instrumentation

\section{ResUMo}

Objetivo: Avaliar a reprodutibilidade da medida da espessura corneana central, no seu centro geométrico, com medidas obtidas pelo sistema Pentacam de Alta Resolução (HR) com o decorrer do tempo. Métodos: Realizado estudo observacional prospectivo em Centro Oftalmológico. Duas medidas isoladas da espessura central da córnea (ECC) foram realizadas com exame de tomografia do segmento anterior Pentacam HR em períodos com intervalos maiores que 3 e em até 12 meses, sendo então comparadas os resultados. Resultados: Cento e dezesseis olhos $(\mathrm{n}=$ 116) de 62 pacientes saudáveis foram incluídos neste estudo. A média das medidas da ECC na primeira e na última avaliação foi de $541,6 \pm 37 \mu \mathrm{m}$ e $543,6 \pm 36,9 \mu \mathrm{m}$, respectivamente. A diferença média entre as duas medições foi de $9,2 \pm 6,4 \mu \mathrm{m}$, e não houve diferença estatisticamente significativa das medida da ECC entre as visitas, com boa correlação entre si $(\mathrm{P}=0,057, \mathrm{r} 2=0,9209)$. Conclusão: O Tomógrafo de Segmento Anterior Pentacam HR apresentou medidas de ECC reprodutíveis ao longo do tempo.

Descritores: Córnea/anatomia \& histologia; Topografia da córnea; Biometria/métodos; Reprodutibilidade de resultados; Técnicas de diagnostico oftamológico/instrumentação

\footnotetext{
${ }^{1}$ Hospital Santa Casa de Misericórdia do Rio de Janeiro (RJ), Brasil;

${ }^{2}$ Pós-Graduando (Doutorado) do Departamento de Oftalmologia da Universidade Federal de São Paulo (UNIFESP) - São Paulo (SP), Brasil;

${ }^{3}$ Hospital Universitário Antonio Pedro -Niterói - (RJ), Brasil; Professor da Universidade Federal Fluminense (UFF) - Rio de Janeiro (RJ), Brasil;

${ }^{4}$ Instituto de Olhos Renato Ambrósio - Rio de Janeiro (RJ), Brasil.
}

Interest conflict - None
\end{abstract}

Recebido para publicação em 24/1/2011 - Aceito para publicação em 19/6/2011 


\section{INTRODUCTION}

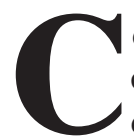
entral corneal thickness measurement is of crucial importance for clinical and surgical decisions in ophthalmology. It gives information regarding corneal endothelial cell function, patient eligibility to different techniques of cataract and refractive surgery, affects intraocular pressure measurement by Goldmann applanation tonometry and is recognized as an independent risk factor for glaucoma progression ${ }^{(1-6)}$. Therefore, investigating different methods of CCT measurements is of special interest.

A number of instruments have been developed to assess CCT, including ultrasonic and optical pachymetry, interferometry, high-frequency ultrasound, corneal confocal microscopy, scanning-slit pachymetry, and non-contact specular microscopy ${ }^{(3)}$. Non-contact methods for measuring CCT are desirable, as they do not have many drawbacks (as probe alignment, corneal indentation, possibility of infection, patient discomfort, damage to corneal epithelium and examiner expertise dependence) related to traditional contact ultrasonic pachymetry. Discrepancies in CCT measurements obtained with different devices are a problem when a patient needs long-term follow-up. Repeatability of a method describes the consistency between readings on the same instrument by the same (intra-observer) or different (inter-observer) observer under constant conditions on different ${ }^{(7,8)}$. High repeatability index improves the ability of the ophthalmologist to diagnose and track changes in patient status during long-term follow-up or detect the effect of a surgical intervention.

The Pentacam HR Comprehensive Eye Scanner (Oculus, Wetzlar, Germany) employs a rotating Scheimpflug camera, providing several information of the anterior segment including three-dimensional images and corneal topography and pachymetry maps. The pachymetry map enables the evaluation of the corneal thickness measurements in its whole area, providing different corneal points, such as at its geometric center, pupil center and the thinnest point. The goal of this study was to evaluate the repeatability of successive CCT measurements over time with the Pentacam system.

\section{MethodS}

A prospective, single center, observational study was designed to follow the tenets of the Declaration of Helsinki. The participants were informed about the purpose of the study and gave informed consent before inclusion. All measurements were taken at least 4 hours after wakening, between $10 \mathrm{AM}$ and $6 \mathrm{PM}$, to minimize the effects of any diurnal variation in CCT. The interval between measurements was 3 to 12 months.

Exclusion criteria were corneal diseases, such as corneal scarring, opacities and Fuch's endothelial dystrophy or history of previous corneal surgery. Contact lenses had to be removed at least 24 hours before measurement in both visits.

The Pentacam HR system is connected to a personal computer, with automated software. The manufacturer performed calibration of the device. The system uses a rotating Scheimpflug camera and a monochromatic slit light source (blue LED at $475 \mathrm{~nm}$ ) that rotate together around the optical axis of the eye.

After proper alignment of patient's face, a fixation target is shown and guides the patient's look. A realtime image of the patient's eye is shown to the examiner on the computer screen, and the image was focused and centered manually.

The rotating camera takes multiple (was set to 25 or 50, depending on the settings) slit images of the anterior eye segment in approximately 2 seconds with 500 true elevation points incorporated in each slit image. Minute eye movements are captured by a second camera and corrected simultaneously. Single point pachymetric measurements of the entire cornea are calculated from the calculated front and back corneal surfaces. The CCT is measured in each of the single images of a scan, giving very accurate and precise values.

All data were entered into a SPSS 12 spreadsheet. The Kolmogorov-Smirnov test was used to check for a normal distribution of quantitative data, which are provided as the mean and standard deviation (SD) - Table 1. Differences between data were evaluated using the Student's twosample t-test, whereas correlation coefficient ( $r$ ) was established by Spearman's rank correlation. The level of significance for each parameter was set at $\mathrm{p}<0.05$.

\section{Results}

One hundred and sixteen eyes of 62 health patients were included in this study. Mean age of studied subjects was $48 \pm 11$ years old (range, $21-72$ ), and female-male ratio was 67:43.

The average measurements of CCT in the first and last visits were $541.6 \pm 37 \mu \mathrm{m}$ and $543.6 \pm 36.9 \mu \mathrm{m}$ respectively. Mean difference between both measurements was $9.2 \pm 6.4 \mu \mathrm{m}$. There was no statistically significant difference in measurement results between both visits, with good correlation between them $\left(\mathrm{P}=0.057, \mathrm{r}^{2}=0,9209\right)$. 
Table 1

Kolmogorov-Smirnov test

\begin{tabular}{llc}
\hline & & DIF \\
\hline $\mathrm{N}$ & Mean & 116 \\
& & 138156 \\
Normal Parameters(a,b) & Std. Deviation & 5011775 \\
& & 398 \\
Most Extreme Differences & Absolute & 398 \\
& Positive & -391 \\
& Negative & 4292 \\
Kolmogorov-Smirnov Z & & 0 \\
Asymp. Sig. (2-tailed) & & \\
\hline
\end{tabular}

Table 2

Paired samples statistics

\begin{tabular}{rcccc}
\hline & Mean & N & Std. Deviation & $\begin{array}{c}\text { Std. Error } \\
\text { Mean }\end{array}$ \\
\hline Pair 1 CCT1 & 5416194 & 116 & 3686481 & 342281 \\
CCT2 & 5435721 & 116 & 3679244 & 341609 \\
\hline
\end{tabular}

\section{Discussion}

Corneal thickness is important to informed the corneal endothelial cell function, patient candidate of cataract and refractive surgery, and can affect intraocular pressure measurement by Goldmann applanation tonometry becoming an independent risk factor for glaucoma progres$\operatorname{sion}^{(1-6)}$. Variations on mesasuremnts represents an important problem because failure to do so may result in misclassification and, thus, an inaccurate assignment of risk.

Shildkrot et al..$^{(5)}$ and Wickham et al..$^{(9)}$ suggested that a single measurement of CCT, given by ultrasonic pachymetry, may no longer suffice for long-term patient follow-up as it has important diagnostic and prognostic components for glaucoma.

Corneal endothelial health can be assessed by tissue transparency and corneal thickness. Changes in these indexes serves as markers for corneal metabolism and hydration control. Inaccurate measurement of CCT can lead to serious complications in refractive surgery and clinical management of glaucoma patients.

Many advantages are observed using non-contact methods to assess CCT as ultrasonic pachymetry measurements, considered the standard method, are subject to physical effects of changes in corneal hydration caused by ultrasound speed passing through the cornea ${ }^{(3,10,11)}$. The Pentacam detects automatically the center of the cornea, thereby reducing the chance of error in establishing this measurement. In addition, there is no need for topical anesthetic drops and one single measurement can be performed instead of repeating several measurements on the same eye and considering the mean among them. The corneal pachymetric map is also provided, and is of clinical relevance ${ }^{(12)}$. It detects not only the thinnest point and its location, but also the rate of corneal thickening toward the periphery, which is altered in some pathologic conditions.

When a new technology is available, it is of great scientific interest to compare it to well-established methods and test its reliability and repeatability. To the best of our knowledge, this is the biggest series of CCT measurement using the Pentacam system. We did not measure eyes with corneal pathologies nor compared its results to other method of CCT measurement, so we cannot make comments regarding these aspects.

In a meta-analysis of CCT measurements, Doughty and $\mathrm{Zaman}^{(3)}$ found a mean corneal thickness for healthy eyes as $534 \mu \mathrm{m}$. Using the Pentacam system, Amano et al. ${ }^{(1)}$ found an average corneal thickness of $538 \pm 31.3 \mu \mathrm{m}$ in 54 Japanese subjects, which were in good correlation with ultrasonic and scanning-slit pachymetry. In agreement with these findings, Buehl et al. ${ }^{(13)}$ and Barkana et al. ${ }^{(14)}$ concluded that the Pentacam is a reproducible, reliable and easy to use non-contact method of measuring CCT.Lackner et al. ${ }^{(15)}$ compared the repeatability and reproducibility of CCT with the Pentacam, Orbscan and ultrasound concluding that Pentacam's reproducibility was the highest of all. O'Donnell et al. ${ }^{(7)}$ found that the Pentacam provided lower CCT measurements when compared with ultrasonic pachymetry, but still gave repeatable results.

Another well studied non-contact method for measuring CCT is the Orbscan II (Bausch \& Lomb, Rochester, NY) $)^{(3,10,11,13,16,17)}$. Giraldez Fernandez et al. ${ }^{(10)}$ found that the Orbscan measurement of CCT were greater that ultrasonic pachymeter measurements, a difference that was statistically significantly. Marsich et al. ${ }^{(8)}$ compared measures of CCT with the Orbscan, ultrasonic pachymetry and optical pachymetry, and concluded that the Orbscan system was the most repeatable technique. However, it showed a significant bias toward greater corneal thickness measures that the other methods.

In conclusion, the Pentacam HR system is a simple, easy-to-use, quick, user independent, and repeatable method to measure the CCT in healthy corneas. It should be considered as an acceptable method in longitudinal and multiple session measurements of CCT. Further studies are needed to establish the role of Pentacam CCT measurements in eyes with corneal disease. 


\section{RefERENCES}

1. Amano S, Honda N, Amano Y, Yamagami S, Miyai T, Samejima $\mathrm{T}$, et al. Comparison of central corneal thickness measurements by rotating Scheimpflug camera, ultrasonic pachymetry, and scanning-slit corneal topography. Ophthalmology. 2006;113(6):937-41.

2. Medeiros FA, Sample PA, Zangwill LM, Bowd C, Aihara M, Weinreb RN. Corneal thickness as a risk factor for visual field loss in patients with preperimetric glaucomatous optic neuropathy. Am J Ophthalmol. 2003;136(5):805-13.

3. Doughty MJ, Zaman ML. Human corneal thickness and its impact on intraocular pressure measures: a review and metaanalysis approach. Surv Ophthalmol. 2000;44(5):367-408.

4. Feltgen N, Leifert D, Funk J. Correlation between central corneal thickness, applanation tonometry, and direct intracameral IOP readings. Br J Ophthalmol. 2001;85(1):85-7.

5. Shildkrot Y, Liebmann JM, Fabijanczyk B, Tello CA, Ritch R. Central corneal thickness measurement in clinical practice. J Glaucoma. 2005;14(5):331-6.

6. Brandt JD, Beiser JA, Kass MA, Gordon MO. Central corneal thickness in the Ocular Hypertension Treatment Study (OHTS). Ophthalmology. 2001;108(10):1779-88.

7. O'Donnell C, Maldonado-Codina C. Agreement and repeatability of central thickness measurement in normal corneas using ultrasound pachymetry and the OCULUS Pentacam. Cornea. 2005;24(8):920-4

8. Marsich MW, Bullimore MA. The repeatability of corneal thickness measures. Cornea. 2000;19(6):792-5.

9. Wickham L, Edmunds B, Murdoch IE. Central corneal thickness: will one measurement suffice? Ophthalmology. 2005;112(2):225-8

10. Giraldez Fernandez MJ, Diaz Rey A, Cerviño A, YebraPimentel E. A comparison of two pachymetric systems: slitscanning and ultrasonic. CLAO J. 2002;28(4):221-3.
11. González-Méijome JM, Cerviño A, Yebra-Pimentel E, Parafita MA. Central and peripheral corneal thickness measurement with Orbscan II and topographical ultrasound pachymetry. J Cataract Refract Surg. 2003;29(1):125-32.

12. Li Y, Shekhar R, Huang D. Corneal pachymetry mapping with high-speed optical coherence tomography. Ophthalmology. 2006;113(5):792-9.e2.

13. Buehl W, Stojanac D, Sacu S, Drexler W, Findl O. Comparison of three methods of measuring corneal thickness and anterior chamber depth. Am J Ophthalmol. 2006;141(1):7-12.

14. Barkana Y, Gerber Y, Elbaz U, Schwartz S, Ken-Dror G, Avni I, Zadok D. Central corneal thickness measurement with the Pentacam Scheimpflug system, optical low-coherence reflectometry pachymeter, and ultrasound pachymetry. J Cataract Refract Surg. 2005;31(9):1729-35.

15. Lackner B, Schmidinger G, Pieh S, Funovics MA, Skorpik C. Repeatability and reproducibility of central corneal thickness measurement with Pentacam, Orbscan, and ultrasound. Optom Vis Sci. 2005;82(10):892-9.

16. Javaloy J, Vidal MT, Villada JR, Artola A, Alió JL. Comparison of four corneal pachymetry technique's in corneal refractive surgery. J Refract Surg. 2004;20(1):29-34.

17. Fam HB, Lim KL, Reinstein DZ. Orbscan global pachymetry: analysis of repeated measures. Optom Vis Sci. 2005;82(12):1047-53.

\section{Corresponding author: \\ Ruiz Simonato Alonso}

Avenida das Américas, 489 Bloco B - Casa 5 - Barra

da Tijuca

CEP 22631-000 - Rio de Janeiro (RJ), Brasil -

Phone: 02171194673 / Fax: 02124955456

E-mail: ruizsa@hotmail.com 